\title{
Morphogenetic Study of Pepino and Other Members of Solanaceae Family
}

\author{
Habib Ahmad1, Ayaz Khan ${ }^{1}$, Khushi Muhammad1*, Muhammad Shahid Nadeem1, \\ Waqar Ahmad1, Sajjad Iqbal'2, Aniqa Nosheen', Nazia Akbar1, Israr Ahmad1, Youxiong Que ${ }^{3}$ \\ ${ }^{1}$ Department of Genetics, Hazara University, Manshera, Pakistan \\ ${ }^{2}$ Institute of Chemical and Biological Sciences, Department of Botany, University of the Gujrat, Gujrat, Pakistan \\ ${ }^{3}$ Key Lab of Sugarcane Biology and Genetic Breeding, Ministry of Agriculture, Fujian Agriculture and Forestry \\ University, Fuzhou, China \\ Email: "khushisbs@yahoo.com, ${ }^{*}$ ayazgenetics@gmail.com
}

Received 2 October 2014; revised 12 November 2014; accepted 28 November 2014

Copyright (C) 2014 by authors and Scientific Research Publishing Inc.

This work is licensed under the Creative Commons Attribution International License (CC BY).

http://creativecommons.org/licenses/by/4.0/

\section{(c) (i) Open Access}

\section{Abstract}

This paper reports the findings regarding morphology, DNA markers and fruit quality of Solanum muricatum L., a newly introduced fruit in Hazara University, Pakistan, and other locally grown members of the Solanaceae family. In this study, RAPD (Random Amplified Polymorphic NA) based PCR report on phylogenetic affinities of pepino with brinjal, chilies, potato and tomato was also included. Total genomic DNA was isolated and 120 arbitrary decamers were applied to the genomic DNA of all these species. Only five out of the 120 decamers produced 27 polymorphic loci with the range of $400-1400 \mathrm{bp}$. We observed the specificity of markers, and primer B-08 amplified 700 bp locus linked to Solanum muricatum L., (Pepino), which could be used to identify this particular species of this family. Cluster analysis was also performed using the DNAMAN software (version 5.2.2.0) against the bivariate data collected from the products of several decamers. The UPGMA (Unweighted pair Group Method with Arithmetic Mean) analyses depicted three distinct groups, i.e. group I sorted out brinjal-tomato, group II sorted out chili-potato and pepino sorted out into its independent group III. Though on the basis of morphological traits pepino clustered with tomato, its DNA analyses proved it as a distinct species, far more related to the tomato. Moreover a total six parameters in biochemical analysis were studied, which revealed that pepino is a juicy fruit with maximum $\mathbf{9 3 . 2 5 \%}$ moisture. This study could be helpful to maximize the new crop pepino in Pakistan.

\section{Keywords}

Phylogeny, Genetic Identity, PCR, Pepino, RAPD

\footnotetext{
${ }^{*}$ Corresponding authors
}

How to cite this paper: Ahmad, H., Khan, A., Muhammad, K., Nadeem, M.S., Ahmad, W., Iqbal, S., Nosheen, A., Akbar, N., Ahmad, I. and Que, Y.X. (2014) Morphogenetic Study of Pepino and Other Members of Solanaceae Family. American Journal of Plant Sciences, 5, 3761-3768. http://dx.doi.org/10.4236/ajps.2014.526393 


\section{Introduction}

The pepino (Solanum muricatum Ait; Solanaceae;) previously not reported from Pakistan, is a herbaceous crop domesticated in pre Columbian times for its juicy fruits [1]. Pepino bears fruit with a sweet smell and yellow skin color with purple bands [2] [3]. It is a delicious flavored fruit similar to honeydew or rock melon. This plant food is considered as a fruit in Europe, and it has been cultivated as a new vegetable in Iran [4]. The variety of fruit size, shape, color and flavor among pepino clones is remarkable. However, in most of the commercial cultivars, the fruits weigh between 100 to $300 \mathrm{~g}$, and are round, ovate or elongate in shape [2].

This fruit is nowadays grown in subtropical climates in other regions of the world, especially America and New Zealand, and as a result, they readily exist in many areas during its regular season [5] [6]. Despite its high yield potential it has not achieved the success of other like tomato (Lycopersicum esculentum Mill.), potato (Solanum tuberosum L.) and pepper (Capsicum annum L.). Only in the recent times pepino fruits have raised an increasing interest in the exotic fruit market in Europe and America [7]. The pepino is usually grown up as an annual crop, but in frost free areas, it is sometimes grown as perennial [8]. In the previous studies, AFLP (Amplified Fragment Length Polymohism), cp-DNA restriction fragment length polymorphisms (RFLPs) and DNA sequence haplotypes were used to understand the domestication and evolution of pepino [9]-[12]. Moreover, different molecular techniques were utilized to establish a protocol for pepino mosaic virus (PMV) disease diagnosis [13] [14].

Due to its experimental simplicity, the use of RAPD as molecular markers for taxonomic and systematic analyses of plants [15], as well as plant breeding and the study of genetic interactions [16] [17], has significantly increased. The present research aims to elaborate pepino on the basis of morphological traits as well as to work out phylogenetic affinities with other Solanaceae crops and to establish a genetic base line for authentication and identification of pepino.

\section{Material and Methods}

\subsection{Plant Material}

Four species viz. tomato (Lycopersicum esculentum Mill.), potato (Solanum tuberosum L.), brinjle (Solanum melangina), chilli(Capsicum annum L.) of the Solanaceae family along with pepino (Solanum muricatum Ait;) were grown in the greenhouse at Department of Genetics, Hazara University, Mansehra, Pakistan.

\subsection{DNA Based Study}

DNA was isolated using protocol developed by Doyle and Doyle (1990) [18] with minor modification. DNA quality and quantity of all these four plants were measured and checked with $1 \%$ agarose/TBE gel. The electrophoresis was used to check the RNA contamination of genomic DNA and the DNA based intensity was compared with DNA marker (Enzynomics Cat \# DM001) for better visual estimation. Different dilution of isolated DNA was prepared $10 \mathrm{ng}, 30 \mathrm{ng}, 50 \mathrm{ng}$ and $100 \mathrm{ng}$ per $\mu \mathrm{l}$ in autoclaved $\mathrm{dd}_{\mathrm{H}} \mathrm{O}$ for PCR optimization and amplification. The random decamers were prepared and obtained from BIONeer and details of markers used in this study are given in Table 1. The molecular data were analyzed using statistical software DNAMAN 5.2.2.0 to construct the dendrogram.

Using standard conditions, polymerase chain reaction (PCR) was performed to amplify all DNA samples. The

Table 1. List of RAPD primers used for phylogenetic elaboration. Source: The random decamers were obtained from BIONeer.

\begin{tabular}{cccccc}
\hline S. NO. & Primer name & Sequence [5'-3’] & MOL.WT. & GC contents (\%) & TM $^{\circ} \mathrm{C}$ \\
\hline 1 & A-09 & GGGTAACGCC & 3053.0 & 70.0 & $34.0^{\circ} \mathrm{C}$ \\
2 & A-18 & AGGTGACCGT & 3068.0 & 60.0 & $32.0^{\circ} \mathrm{C}$ \\
3 & B-08 & GTCCACACGG & 3013.0 & 70.0 & $34.0^{\circ} \mathrm{C}$ \\
4 & B-18 & CCACAGCAGT & 2997.0 & 60.0 & $32.0^{\circ} \mathrm{C}$ \\
5 & B-19 & ACCCCCGAAG & 2981.9 & 70.0 & $34.0^{\circ} \mathrm{C}$ \\
\hline
\end{tabular}


commercial Taq polymerase kits were ordered from Enzynomics, Korea. All PCR products were resolved by electrophoresis along with the DNA marker on 1.5\% agarose gel, prepared in 0.5X TBE (Tris/Borate/EDTA) buffer. The electrophoretic file image was documented using gel documentation. The amplification of PCR products was done twice or thrice for reproducibility of band scoring. The sizes of amplified RAPD-DNA fragments (bp) were estimated by reference to a known DNA marker. Those amplified fragments were compared and used in statistical processing which shared over the two or three PCR runs. The presence or absence of fragments was recorded as either 0 (absent) or 1 (present). The binary data set was recorded on a separate sheet for further processing.

\subsection{Morphological Characterization}

The genetic relationship of taxa belonging to the section was investigated by using different morphological markers, to reveal the confusion around the relationship and origin of pepino and other members. The following quantitative and qualitative morphological characters were investigated: leaf width, leaf length, leaf apex, stipule, petiole length, inflorescence, number of nodes, inter node length, plant hairiness, leaf venation, leaf bifacility, pedicel length, flower color and anther length. For quantitative characters, their average values were used. Qualitative characters were recorded in binary state and in some cases in multiple states. The binary characters were recorded as 1 and 2. Multiple state characters were recorded as 1,2 , and 3 . The parameters selected for numerical analyses were the same as those proposed by Abid and Qaiser (2006) [19]. Minitab was used for morphological data analysis.

\subsection{Biochemical Analysis of Pepino}

The fruits of the pepino were sent commercially to Pakistan Council of Scientific and Industrial Research (PCSIR) laboratory Peshawar for analysis of volatile constituents of the fruit. A total of 6 volatiles, including total ash (\%), total juice recovery (\%), crude fat (\%), crude protein (\%), carbohydrates (\%) and crude fiber were identified.

\section{Results}

Four members of the family along with pepino were used for DNA analysis. Using the local conditions of equipment's and chemicals, a protocol for extraction of total genomic DNA was optimized. In the modified DNA extraction protocol the expensive reagent liquid nitrogen was replaced. Quality and quantity of DNA isolated was confirmed by $1 \%$ agarose/TBE gel. The spectrophotometry of genomic DNA provides evidence of good quality \& high molecular, with no or minimum degradation and with no contamination of RNA.

Typically a PCR requires 50 - 100 ng DNA as a template. The DNA isolated was diluted. Different dilution of isolated DNA was prepared $10 \mathrm{ng}, 30 \mathrm{ng}, 50 \mathrm{ng}$ and $100 \mathrm{ng}$ per $\mu \mathrm{l}$ in the autoclaved water. One $\mu \mathrm{l}$ DNA was used in the PCR reaction.

In the present study, RAPD-PCRs were carried out using 120 decarmers. The only 5 random amplified polymorphic DNA decamers were selected on the basis of reproducibility and polymorphism to amplify genomic DNA from 4 members of Solanaceae along with pepino. Two separate PCRs were conducted using primer sets A-09 and A-18 in the first PCR reaction and B-08, B-18 \& B-19 in the second PCR reaction.

In few samples, amplification was not observed, which might due to the annealing sites of the primer used (A $=09$ ) were not present in the genotypes. It is visible that the DNA fragments amplified in various genotypes were of various sizes ranging from $400 \mathrm{bp}$ to $1400 \mathrm{bp}$.

The five selected primers produced 29 detectable polymorphic amplicons in our DNA samples with the mean of 5.4 loci per primer. The number of amplified loci ranged from 400 bp to $1400 \mathrm{bp}$ and all used primers showed $100 \%$ polymorphism (Table 2). The least number of bands was amplified with primer B = 08 (GTCCACACGG), while the maximum number of loci was amplified with primer A = 18 (AGGTGACCGT). One locus with 700 bp was identified to linked to pepino and it was produced by primer B-08.

The dendogram resulted by DNAMAN (Figure 1) showed different patterns of polymorphism in RAPDPCR. Homology tree divides five members of the family Solanaceae into III major groups with 2 subgroup “2a” and " $2 \mathrm{~b}$ ” in group 2. Subgroup "2a" comprised brinjal and tomato which have $80 \%$ homology, while subgroup " $2 \mathrm{~b}$ ” contain chilly and potato and have 88\% identical. Between group 1 and 2, 68\% homology was analyzed. 
Table 2. Data analysis of decamers used in the present study.

\begin{tabular}{cccccccc}
\hline S. NO. & Primer & Sequence & T.B & M.B & P.B & PP\% & Range of bands \\
\hline 1 & A-09 & GGGTAACGCC & 7 & 0 & 7 & $100 \%$ & $400-1100$ \\
2 & A-18 & AGGTGACCGT & 9 & 0 & 9 & $100 \%$ & $500-1400$ \\
3 & B-08 & GTCCACACGG & 3 & 0 & 3 & $100 \%$ & $900-1400$ \\
4 & B-18 & CCACAGCAGT & 5 & 0 & 5 & $100 \%$ & $500-1000$ \\
5 & B-19 ACCCCCGAAG & 5 & 0 & 5 & $100 \%$ & $300-1000$ \\
\multicolumn{2}{c}{ Total bands } & 29 & 0 & 29 & & \\
\hline
\end{tabular}

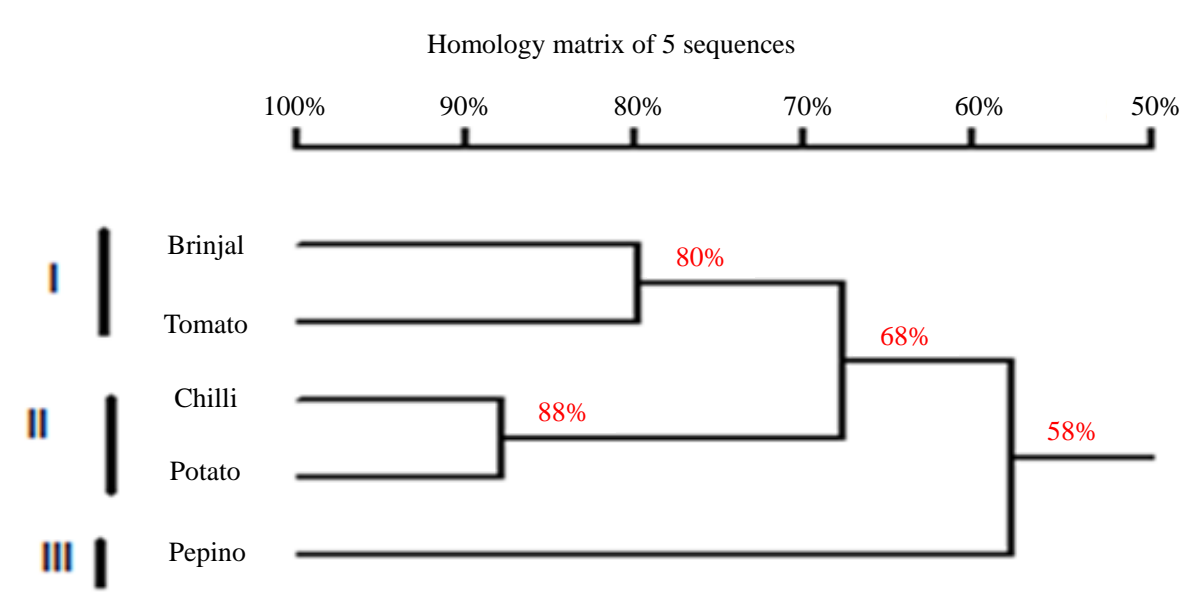

Figure 1. Homology tree constructed against four accessions of the Solanaceae family along with pepino using DNAMAN software based on Nei's coefficient.

Pepino was included in group 3 showing 58\% homology with the rest of the two groups and similarly based on a distance metrice, it was clustered in group III (Figure 2).

Moreover, the morphological diversity among members of Solanaceae family was calculated. During construction of morphological dendrogram, two major groups, i.e. A and B were generated (Figure 3). The group A comprised of pepino and tomato with $47.70 \%$ homology, while group B further consists of two clusters as I and II. Brinjal and potato in sub group I showed $97.3 \%$ homology and subgroup II comprised of chilly and similarity index 63.94\% was seen between subgroup 1 and 2.

Furthermore, the qualitative analysis of pepino fruit was investigated. For this purpose, a total of 6 volatiles, including total ash, total juice recovery, crude fat, crude protein, carbohydrates and crude fiber were identified in PCSIR Peshawar (Table 3). AOAC official method of analysis 2005 was used for the chemical analysis of the fruit. During biochemical study, we found more 93\% juice recovery. Other parameters, i.e. total ash crude fat and crude protein were also observed, but the most important was crude fiber amount.

\section{Discussion}

The pepino (Solanum muricatum) is an herbaceous crop cultivated in pre Columbian times for its juicy fruits [1]. Pepino is a fruit plant with a sweet smell and yellow coating color with purple stripes [3]. The anti-tumors effect of pepino has been reported [20]. Molecular markers can provide a prevailing tool to unravel the genome of medicinal important plant and enhance the discovery of Mendelian bases for trait inheritance [21]. In recent years, the use of molecular markers in crops has increased rapidly. With the use of molecular techniques, it would now be possible to accelerate the identification of different varieties and species of plants. Recently, many studies were performed for DNA fingerprinting of different economical plants for conservation and exploitation of genetic resources [22]. Among the PCR-based molecular techniques, random amplified polymorphic DNA (RAPD) is opportune in performance and does not require any information about the DNA sequence to be amplified [23]. 


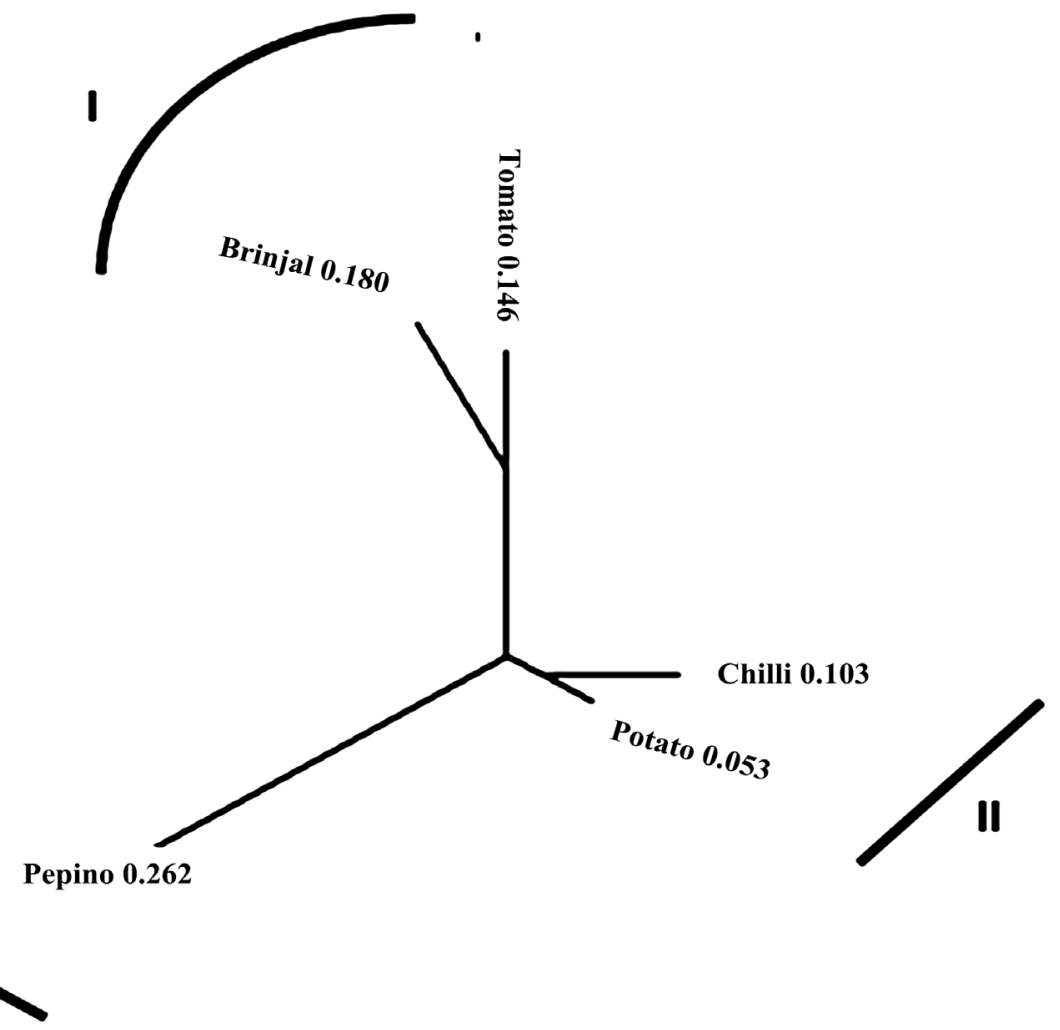

Figure 2. Genetic distance among pepino and other specimens of family Solanaceae.

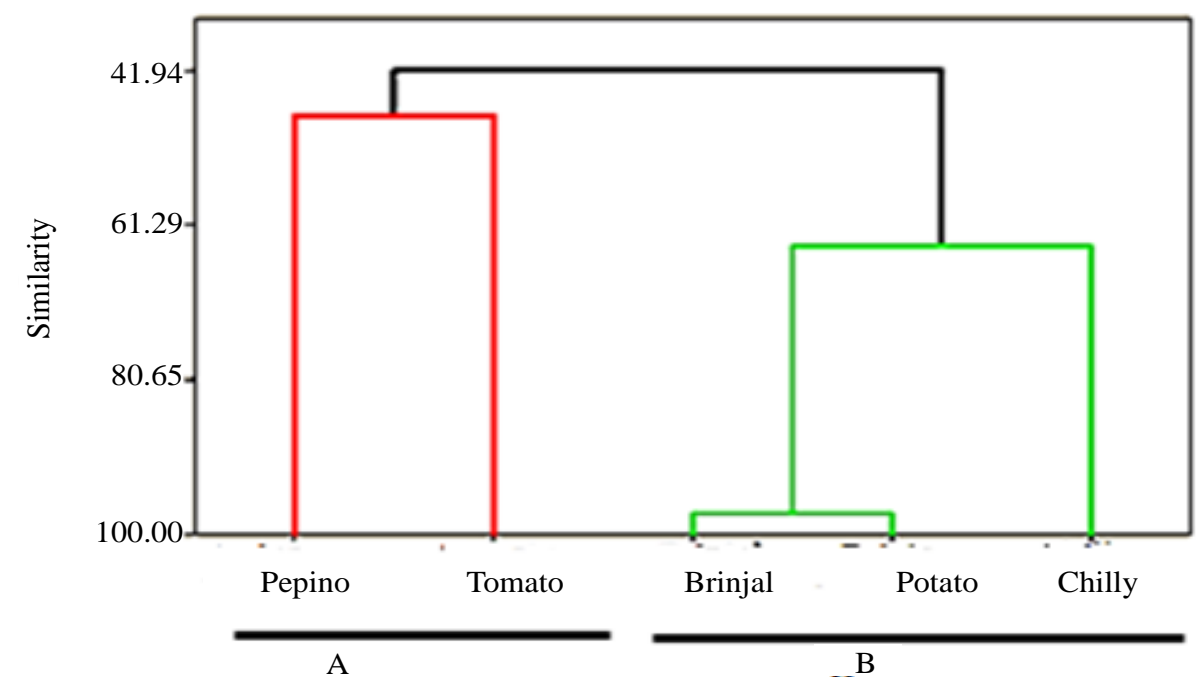

Figure 3. Morphological diversity between pepino and other specimen of family Solanaceae.

Table 3. Chemical analysis of pepino fruit.

\begin{tabular}{ccc}
\hline S. NO. & Parameters & Results \\
\hline 1 & Total ash \% & 0.20 \\
2 & Juice recovery \% & 93.25 \\
3 & Crude fat \% & 0.03 \\
4 & Crude protein \% & 0.40 \\
5 & Carbohydrate \% & 5.66 \\
6 & Crude fiber \% & 0.46 \\
\hline
\end{tabular}


The main goal of this work was to determine the feasibility of using RAPD markers as a tool to estimate diversity in different members of the family Solanaceae. The RAPD markers were used effectively for determining the phylogenetic relationships among the five specimens of Solanaceae. Many researchers have used this technique to determine phylogeny among genotypes of various valuable crops [17] [24].

In the present work, based on five markers, 29 RAPD loci showed $100 \%$ polymorphism among five specimens of Solanaceae from Pakistan to reveal their genetic similarity and genetic distances. We observed the highest polymorphism, which is the most important feature of any marker to identify species or accessions of crops. The genetic variation through RAPD markers has been highlighted in a number of medicinal plants [24]-[26]. In previous studies, pepino and some members of Solanaceae family were characterized using AFLP techniques [10] [12].

In phylogenetic study, the cluster analysis, among the four Pakistani Solanaceae specimens along with pepino, showed a noteworthy relationship to make distinct groups of species. Selvi et al. (2003) [27] concluded that the success of a breeding program depends on the understanding of the extent of variation bearing on the available gene pool. It is providing useful information for clustering of different species of medicinally important crops to conserve and utilize genetic resources. We were also able to locate a specific locus linked to the particular accession of the family Solanaceae. These specific loci will be available for estimation and characterization of genome complexity and diversity among different species of crops.

In the present research, the morphology of pepino along with other member of family Solanceae was also studied. On the basis of morphological marker, pepino was phylogenetically close to tomato and has similar physiological requirements, although it develops more slowly and requires at least 7 - 8 more weeks from uprooting to the completion of the growing cycle [28]. The phylogenetic tree of morphology showed that pepino is mostly close to tomato.

Pepino fruit is low in calories, very rich in minerals such as calcium, phosphorus and potassium and contains vitamins such as thiamin, niacin, riboflavin and ascorbic acid (vitamin C), ideal for a number of metabolic and antioxidant reactions [29]. In the present study, the biochemical components of the pepino were also analyzed. A total of six parameters were studied, which revealed that pepino is a juicy fruit with maximum $93.25 \%$ moisture. This research is covering different types of parameters to evaluate selected members of Solanaceae family and pepino. We also evaluated fruit quality of pepino grown in the garden of Hazara University, Mansehra and this study should be useful to maximize this crop in this region.

\section{Conclusion}

Different members of the Solanaceae family along with pepino were cultivated at $34^{\circ} 20^{\prime} \mathrm{N} 73^{\circ} 12^{\prime} \mathrm{E}$ in Hazara University, Mansehra Pakistan. These were characterized with morphological and molecular markers. After screening with RAPD markers, five primers were selected because of the high degree of polymorphism. The specificity of the markers was also observed and primer B-09 generated $700 \mathrm{bp}$ locus linked to pepino and this could be further used to develop specific marker. The cluster analysis was also performed based on DNA markers and morphological data. Two different patterns were observed while analyzing these two types of data. Moreover, the fruit quality of pepino was studied and high quality of fruit was reported.

\section{Acknowledgements}

The authors are thankful to Directorate of Science and technology (DOST) KP Pakistan for funding.

\section{References}

[1] Prohens, J., Ruiz, J.J. and Nuez, F. (1996) Pepino (Solanum muricatum; Solanece) a New Crop with History. Economics of Botany, 50, 355-368. http://dx.doi.org/10.1007/BF02866518

[2] Ruiz, J.J. and Nuez, F. (1997) Pepino (Solanum muricatum Ait.) an Alternative Crop for Areas Affected by Moderate Salinity and Fruit Quality of Pepino Clone. Horticulture Science, 32, 649-652.

[3] Cheng, C.Y., Rguo, H., Wang, Z. and Yin, M.C. (2011) Protective Effects of an Aqueous Extract from Pepino (Solanum muricatum Ait.) India Beticmice.

[4] Nemati, S.H., Karimian, Z., Tehranifar, A., Mashhadian, N.V. and Lakzian (2009) Investigation of Some Effective Factors on Yield Traits of Pepino (Solanumm muricatum) as a New Vegetable in Iran. Pakistan Journal of Biological Sciences, 12, 492-497. http://dx.doi.org/10.3923/pjbs.2009.492.497 
[5] Prohens, J., Ruiz, J.J. and Nuez, F. (1999) Yield, Earliness and Fruit Quality of Pepino Clones and Their Hybrids in the Autumn-Winter Cycle. Journal of the Science of Food Agricultural, 79, 340-346. http://dx.doi.org/10.1002/(SICI)1097-0010(199902)79:2<340::AID-JSFA205>3.0.CO;2-\#

[6] Prohens, J. and Nuez, F. (1999) Strategies for Breeding a New Greenhouse Crop the Pepino (Solanum muricatum Aiton). Canadian Journal of Plant Science, 79, 269-275. http://dx.doi.org/10.4141/P98-058

[7] Anonymous (1989) Lost Crop of the Incas Little Known Plants of the Andes with Promise for Worldwide Cultivation. National Academy Press, Washington DC.

[8] Bravo, A. and Arias, E. (1983) Cultivo del Pepinodulce. Antecedentes Agronomics y Economics. EI Campenino, 114, 15-34.

[9] Spooner, D.M. Anderson, G.J. and Jansen, R.K. (1993) Chloroplast DNA Evidence for the Interrelationships of Tomatoes, Potatoes, and Pepinos (Solanaceae). American Journal of Botany, 80, 676-688. http://dx.doi.org/10.2307/2445438

[10] Anderson, G.J., Jansen, R.K. and Kim, Y. (1996) The Origin and Relationships of the Pepino. Solanum muricatum (Solanaceae): DNA Restriction Fragment Evidence. Economic Botany, 50, 369-380. http://dx.doi.org/10.1007/BF02866519

[11] Anderson, G.J. and Jansen, R.K. (1998) Biosystematic and Molecular Systematic Studies of Solanum Section Basarthrum and the Origin and Relationships of the Pepino Dulce (S. muricatum). Monographs in Systematic Botany from the Missouri Botanical Garden, 68, 17-32.

[12] Blanca, J.M., Prohens, J., Anderson, G.J., Zuriaga, E., Cañizares, J. and Nuez, F. (2007) AFLP and DNA Sequence Variation in an Andean Domesticate, Pepino (Solanum muricatum, Solanaceae): Implications for Evolution and Domestication. American Journal of Botany, 94, 1219-1229. http://dx.doi.org/10.3732/ajb.94.7.1219

[13] Aguilar, J.M., Hernández-Gallardo, M.D., Cenis, J.L., Lacasa, A. and Aranda M.A. (2002) Complete Sequence of the Pepino Mosaic RNA Genome. Archives of Virology, 147, 2009-2015. http://dx.doi.org/10.1007/s00705-002-0848-9

[14] Mansilla, C., Sánchez, F. and Ponz, F. (2003) The Diagnosis of the Tomato Variant of Pepino Mosaic Virus: An IC-RT-PCR Approach. European Journal of Plant Pathology, 109, 139-146. http://dx.doi.org/10.1023/A:1022550502049

[15] Bartish, I.V., Garkava, L.P., Rumpunen, K. and Nybom, H. (2000) Phylogenetic Relationship and Differentiation among and within Population of Chaenomeles Lindl. (Rosaceae) Estimated with RAPDs and Isozyme. Theoretical Applied Genetics, 101, 554-563. http://dx.doi.org/10.1007/s001220051515

[16] Ranade, S., Farooqui, A.N., Bhattacharya, E. and Verma, A. (2001) Gene Tagging with Random Amplified Polymorphic DNA (RAPD) Marker for Molecular Breeding in Plants. Critical Reviews in Plant Sciences, 20, 251-275. http://dx.doi.org/10.1080/20013591099227

[17] Muhammad, K., Afghan, S., Pan, Y.B. and Iqbal, J. (2013) Genetic Variability among the Brown Rust Resistant and Susceptible Genotypes of Sugarcane by RAPD Technique. Pakistan Journal of Botany, 45, 163-168.

[18] Doyle, J. and Doyle, J.L. (1990) Isolation of Plant DNA from Fresh Tissue. Focus, 12, 13-15.

[19] Abid, R. and Qaiser, M. (2006) Numerical Analysis of Inula and Its Allied Genera from Pakistan and Kashimar. Pakistan Journal of Botany, 38, 521-526.

[20] Ren, W. and Tang, D.G. (1999) Extract of Solanum muricatum (Pepino/CSG) Inhibits Tumor Growth by Inducing Apoptosis. Anticancer Research, 19, 403-408.

[21] Aitken, K. S., Jackson, P.A and Mcintyre, C.L.A. (2005) A Combination of AFLP and SSR Markers Provides Extensive Map Coverage and Identification of Homo (eo) Logous Linkage Groups in a Sugarcane Cultivar. Theoretical Applied Genetics, 110, 789-801. http://dx.doi.org/10.1007/s00122-004-1813-7

[22] Harisaranraj, R., Suresh, K. and Saravanababu, S. (2009) DNA Finger Printing Analysis among Eight Varieties of Zingiber officinale Rosc. By Using RAPD Markers. Global Journa of Molecular Science, 4, 103-107.

[23] Weder, J.K.P. (2002) Influence of Experimental Conditions on the Reproducibility of RAPD-PCR Identification of Legumes and Cereals. LWT-Food Science and Technology, 35, 233-238. http://dx.doi.org/10.1006/fstl.2001.0844

[24] Surgun, Y., Col, B. and Burun, B. (2012) Genetic Diversity and Identification of Some Turkish Cotton Genotypes (Gossypium hirsutum L.) by RAPD-PCR Analysis. Turkish Journal of Biology, 36, 143-150.

[25] Nayak, S., Naik, P.K., Acharya, L., Mukherjee, A.K., Panda, P.C. and Das, P. (2005) Assessment of Genetic Diversity among 16 Promising Cultivars of Ginger Using Cytological and Molecular Markers. Zeitschrift für Naturforschung, 60, 485-492.

[26] Rout, G.R. (2006) Identification of Tinospora cordifolia (Wild.) Miers ex Hook F and Thomas Using RAPD Markers. Zeitschrift für Naturforschung, 61, 118-122.

[27] Selvi, A., Nair, N.V., Balasundaram, N. and Mohapatra, T. (2003) Assessment of Diversity and Phylogenetic Rela- 
tionships in the Saccharum Complex Using Molecular Markers. Sugarcane Breeding Institute, Coimbatore, India.

[28] Ploetz, R., Heine, G., Hayne, S.J. and Watson, M. (2002) An Investigation of Biological Attributes That May Contribute to the Importance of Phytophthora Capsici as a Vegetable Pathogen in Florida. Annals of Applied Biology, 140, 61-67. http://dx.doi.org/10.1111/j.1744-7348.2002.tb00157.x

[29] Diaz, L. (2006) Industrialización ya provechamiento de productos y sub-productos derivados de materiasprimasagropecuarias de la región de Coquimbo. LOM Ediciones Ltda, Santiago. 
Scientific Research Publishing (SCIRP) is one of the largest Open Access journal publishers. It is currently publishing more than 200 open access, online, peer-reviewed journals covering a wide range of academic disciplines. SCIRP serves the worldwide academic communities and contributes to the progress and application of science with its publication.

Other selected journals from SCIRP are listed as below. Submit your manuscript to us via either submit@scirp.org or Online Submission Portal.
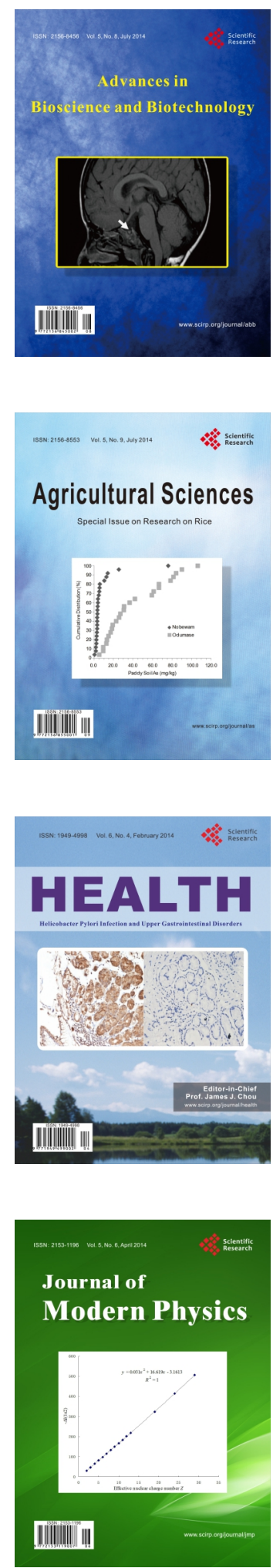
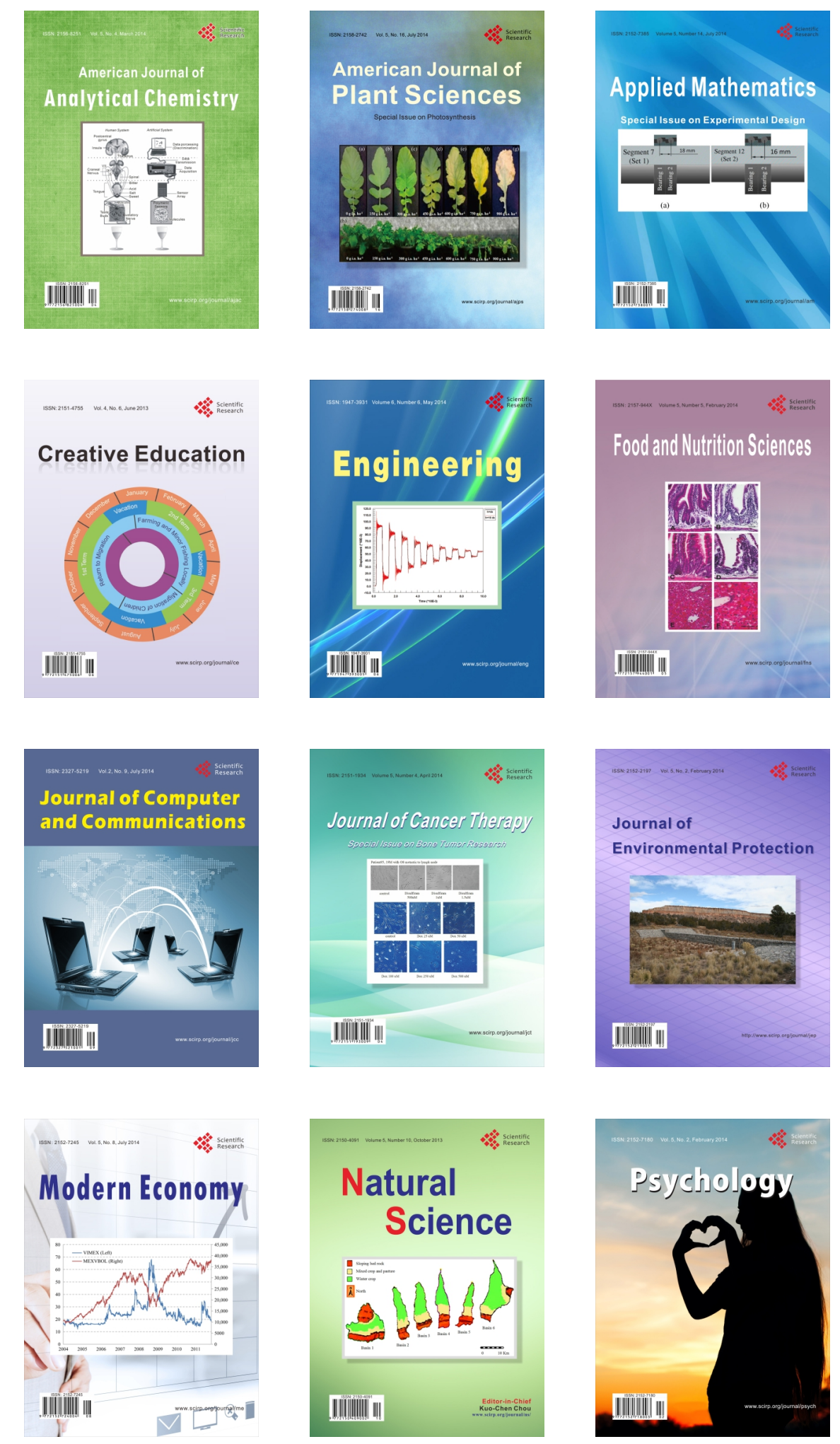